Nordisk Tidsskrift for Kriminalvidenskab 2010

\title{
JuSTITSMINISTERENS TALE VED NORDISK KRIMINALISTMøDE DEN 19. AUGUST 2010
}

Allerførst vil jeg gerne sige mange tak for invitationen. Jeg er meget glad for at kunne få lov til at byde velkommen til dette nordiske kriminalistmøde netop her på Københavns Universitetet, hvor jeg i øvrigt selv har suget visdom - og ikke mindst min juridiske embedseksamen - til mig. Det skaber nogle relevante, højtidelige og ikke mindst smukke rammer for de mange, interessante oplæg, og jeg er ikke i tvivl om, at jeres konference de kommende dage vil være præget af både spændende og frugtbare diskussioner, der på et højt akademisk niveau bidrager til at kvalificere den offentlige debat.

De nordiske kriminalistforeninger har en lang og glorværdig historie. Den danske forening blev grundlagt allerede i 1899, og er en forening, der har ry for at være helt enestående med en bred medlemsskare af de absolut bedste eksperter på området.

Foreningen er vigtig for mig og andre politikere, fordi I skaber et bedre og mere oplyst grundlag for den retspolitiske debat. Mange af jer giver i kraft af jeres professionelle position jeres mening til kende i forbindelse med de høringsprocedurer, som i vore dage indgår som et væsentligt element i lovgivningsprocessen. Og det er af allerstørste vigtighed, for det er næppe nogen hemmelighed, at akademikere og politikere kan se en sag fra meget forskellige synsvinkler.

Derudover er det nordiske samarbejde i sig selv meget værdifuldt. Det er kendetegnet ved, at vi har en kulturelt forankret, fælles interesse og ser med samme optik på de mange udfordringer, som et moderne retssamfund skaber. Det er i mine øjne en helt uvurderlig styrke for os at samarbejde tæt med hinanden og holde kontakten ved lige ved møder som dette. Jeg har netop selv haft fornøjelsen af at være vært ved et vældig godt møde med de nordiske justitsministre, hvor vi også adresserede flere af de emner, som jeg ved optager jer.

Kriminalitet og kriminalitetsbekæmpelse er selvsagt emner, jeg som justitsminister er meget optaget af. Ja, faktisk ser jeg det som min fremmeste opgave at sikre lov og orden, så vi fortsat kan leve i frihed, tillid og tryghed. Lov og orden er imidlertid et udtryk, der let bliver indholdsløst og gammeldags, hvis det ikke forklares og foldes ud - eller med et andet ord: moderniseres.

Lov og orden er efter min opfattelse udtryk for den grundlæggende værdi, at lovgivningen skal overholdes, så samfundet kan fungere effektivt uden uro og forstyrrelser. Vi skal kunne færdes frit og uden frygt i gaderne, forlade vores hjem uden væsentlig risiko for at opleve indbrud, og vi skal ikke mindst kunne indgå aftaler med hinanden i tillid til, at vi ikke bliver snydt og bedraget. Kort sagt: Den personlige frihed, der er kendetegnende for et moderne demokrati, skal have de 
bedste betingelser. Regeringens overordnede målsætning på det retspolitiske område er da også, at danskerne skal være et af verdens mest tillidsfulde og trygge folk.

Lov og orden associeres ofte med en stram retspolitik, hvor der sættes ind med konsekvens og mærkbar straf over for kriminalitet. Og hvor politiet har betydelige ressourcer, er til stede $\mathrm{i}$ gadebilledet $\mathrm{og}$ kan sætte effektivt og håndfast ind over for ulovligheder. Den form for lov og orden går jeg som konservativ justitsminister i en borgerlig regering fuldt ud ind for.

Men lov og orden i en moderne udgave er mere end blot en stram retspolitik, hvor der sættes ind over for forbrydere med politi og strengere straffe. Målet $\mathrm{i}$ et samfund præget af lov og orden må være at bekæmpe - ja, ideelt set helt undgå kriminalitet med effektiv forebyggelse som det fornemmeste middel. Netop derfor udgør den forebyggende indsats mod kriminalitet en central del af regeringens seneste arbejdsprogram, ligesom det kriminalpræventive arbejde er en af mine absolutte topprioriteter.

Vi skal gøre alt, hvad der står i vores magt for at hindre, at unge mennesker kommer ind i en kriminel løbebane til skade for både dem selv og samfundet. Derfor lancerede regeringen i foråret initiativet $\mathrm{Ny}$ Start, der sætter massivt ind over for ungdomskriminalitet.

Udspillet tiltrak mest opmærksomhed på grund af nedsættelsen af den kriminelle lavalder, men jeg vil gerne understrege, at initiativet omfatter en lang række initiativer, der styrker den kriminalpræventive indsats. Eksempelvis ungesamråd i alle politikredse, særlige unge-dommere ved byretterne og ikke mindst en forebyggende indsats på det sociale område, der blandt andet forbedrer mulighederne for at identificere børn og unge med høj kriminalitetsrisiko og bidrager til, at de får den nødvendige støtte til at komme ind i en positiv udvikling.

På samme måde har jeg været optaget af mulighederne for at styrke det $\mathrm{i}$ forvejen gode arbejde, der gøres for at sluse indsatte i fængslerne ud i samfundet på en ordentlig måde. Det er vigtigt og i alles interesse, at indsatte efter endt straf kan blive gode borgere, der kan bidrage positivt til både deres egen og samfundets udvikling.

Jeg har derfor iværksat en undersøgelse af, hvad der kan gøres for at styrke udslusningsindsatsen - både i forhold til Kriminalforsorgen og de sociale myndigheder. For at sikre en bred og fælles indsats involverer undersøgelsen en lang række ministerier og andre interessenter i arbejdet med udslusning, herunder Socialministeriet, Beskæftigelsesministeriet og Undervisningsministeriet.

Netop den tværgående og brede indsats er efter min opfattelse helt afgørende for en succesfuld kriminalitetsforebyggelse. Hvis det gode kriminalpræventive ar- 
bejde, der hver dag udføres af politi, domstole og fængselsvæsen, skal styrkes, er det vigtigt, at vi også fokuserer på det tværfaglige samarbejde og drager nytte af hinandens styrker og kvalifikationer på tværs af faggrupper og ressortområder.

Et andet godt eksempel på et sådant tværfagligt initiativ er regeringens indbrudspakke fra foråret, der sikrer, at der bliver gjort en særlig indsats mod indbrud i private hjem. Denne type kriminalitet er desværre stigende, og derfor præsenterede Justitsministeriet i tæt samarbejde med forsikringsbranchen og Det Kriminalpræventive Råd en fælles helhedsorienteret indsats til forebyggelse og bekæmpelse af indbrud i private hjem.

Jeg vil heller ikke undlade at nævne regeringens ghettostrategi, der sætter målrettet ind over for både fysiske rammer og beboersammensætning i ghettoområder. Arbejdet er forankret i Socialministeriet, men herudover deltager en lang række andre ministerier, bl.a. Integrations-, Undervisnings-, Miljø- og Finansministeriet.

Jeg nævnte før, at jeg som justitsminister i en borgerlig regering går ind for en fast retspolitik, hvor der sættes ind med konsekvens og mærkbar straf over for kriminalitet. Det betyder også, at regeringens fokus på strafniveauet efter min opfattelse er et nødvendigt, men - som det forhåbentlig også er fremgået - ingenlunde tilstrækkeligt element i regeringens samlede kriminalitetsforebyggende tiltag. Man kan også sige, at kriminalpolitiken skal have to ben at gå på.

For så vidt angår fængselsstraffen, der - i et liberalt demokrati - må være det absolut mest vidtrækkende indgreb i menneskers frihed, er det en meget væsentlig retspolitisk opgave at finde den rette balance. Een ting er akademikernes og politikernes retsfølelse og holdning til strafniveauet, men noget andet og mindst ligeså væsentligt er selvfølgelig befolkningens retsfølelse.

På den ene side skal vi naturligvis undgå, at straffen bliver så lav, at den mister sin afskrækkende eller generalpræventive virkning, eller at borgerne ligefrem griber til selvtægt, fordi de oplever straffene som utilstrækkelige. På den anden side skal vi heller ikke straffe mere end nødvendigt. Straf er jo ikke altid et positivt virkemiddel. Derfor er borgernes retsfølelse og retsbevidsthed et udfordrende, nødvendigt og uhyre væsentligt aspekt af enhver retspolitisk problemstilling.

Derfor vil jeg også med særlig interesse læse Flemming Balvigs undersøgelse om danskernes retsfølelse og retsfornuft, for jeg er naturligvis optaget af, om vi har strammet for meget (eller for lidt) i forhold til befolkningens retsfølelse. Jeg har indtil videre kun haft lejlighed til at læse sammenfatningen, men det har allerede givet stof til eftertanke. Det er tankevækkende, at en stor del af befolkningen tilsyneladende kraftigt undervurderer det reelle strafniveau.

Uden at fratage mig selv muligheden for senere at kunne reflektere nærmere over undersøgelsens resultater, er det min opfattelse, at de strafskærpelser, som er 
indført under den nuværende regering, er udtryk for den rette balance, og at det nu er rigtigst - som vi i regeringen gør - i højere grad at vende blikket mod den tværfaglige og helhedsorienterede forebyggende indsats.

Men det er måske netop et udtryk for de forskellige synsvinkler, som vi anskuer verdenen fra. Under alle omstændigheder er jeg meget spændt på senere i dag at høre mere om resultaterne af undersøgelsen.

Da jeg med stor interesse har læst jeres konferenceprogram, ved jeg også, at flere andre af jer senere i dag og de følgende dage formentlig vil udfordre regeringens retspolitik - og det glæder mig! For selvom der kan være forskellige opfattelser om forholdene i det danske samfund (ja, måske netop derfor), skal vi selvfølgelig udfordres, for vi kan hele tiden blive klogere. Det fælles mål må være at skabe de bedste rammer for, at den enkelte borger kan leve i frihed, tillid og tryghed.

$\mathrm{Nu}$ har jeg kun tilbage at ønske jer nogle gode og udbytterige dage her i København. Rigtig godt møde!

Tak. 